Article

\title{
Exploring Factors Affecting Sustainable Innovation Performance of Food Firms. A Case of Korean Food Industry
}

\author{
Harry Jeong and Kwangsoo Shin * \\ Department of Biomedical Convergence, College of Medicine, Chungbuk National University, Cheong-Ju 28644, \\ Korea; harry@g.cbnu.ac.kr \\ * Correspondence: sksidea@chungbuk.ac.kr; Tel.: +82-43-261-2858
}

Received: 10 October 2020; Accepted: 2 December 2020; Published: 4 December 2020

check for updates

\begin{abstract}
This study examines the influence of government support, research and development (R\&D) investment and cooperation networks on sustainable innovation performance of the medium-sized food firms in South Korea. Climate change, population growth, lifestyle change and consumer demands for new products allow firms to explore innovation for sustainable growth. In the food industry, where various stakeholders are involved in the value chain, government support, R\&D investment and cooperation are affecting firms' sustainable performance. However, there are few empirical studies that examine the relationship among them, especially regarding medium-sized food firms. This study aimed to analyze data regarding Korean food firms through a structural equation model. To overcome data scarcity, this study collected new data for 67 medium-sized food firms. The data is matched with the firms' 10-year data on management, innovation performance, and cooperation networks. This study can contribute to filling the literature gap by exploring what innovation strategies should be used to improve food SMEs' innovation performance in the latecomer countries, which have developed their food industries relatively recently.
\end{abstract}

Keywords: food industry; latecomer country; government support; alliance with university; alliance with firm; sustainable innovation performance

\section{Introduction}

Accelerated technological growth, shortened product life cycles and intensifying global competition are rapidly changing the environment surrounding modern firms. Furthermore, agricultural production fluctuates irregularly due to climate change [1] and demand for food is increasing on account of population growth. Increases in income level and changes in lifestyle lead to a new type of food. This is an era in which consumers simply break away from end-users and actively tell producers what they want to eat [2]. In an age of short change cycles, food firms obsessed with past strategies have struggled to survive in the market. Food firms rush to introduce innovation strategies for sustainable growth.

Only a few food firms can meet the increased demands of consumers on their own, whereas the majority need external resources [3]. Firms that do not utilize external knowledge cannot compete in the market in an effective way [4]. Hewitt-Dundas [5] argued that externally sourced knowledge might take the form of partnerships with other organizations, such as suppliers, customers, private research laboratories and government research agencies. Firms make cooperative networks to quickly access new technologies or new markets, to benefit from economies of scale, to share the risks of additional activities [6]. It is found that innovation cooperation is becoming increasingly important for small and medium-sized enterprises (SMEs) to improve their innovation, especially in emerging economies and developing countries $[7,8]$. 
SMEs greatly contribute to the economic growth of countries [9]. The innovation performance of SMEs has various ripple effects as well as contributing to firms' growth. SMEs' R\&D investment, new product development, and innovation outcomes lead to job creation and the emergence of new industries in the long run $[10,11]$. Nevertheless, SMEs lack capital, research manpower, and technical capabilities compared to large firms. Accordingly, the government has supported SMEs' innovation through policy support. Despite long periods of government support, SMEs still face limitations in their capabilities, and innovation performance falls short of expectations. Therefore, it is necessary to study the sustainable innovation of SMEs.

As such, it was agreed that the formation of partnerships and cooperation in the food industry are necessary to achieve sustainable competitive advantages of firms. Nevertheless, most of the existing studies have been conducted in advanced countries [12], and empirical studies that have examined increasing innovation performance in the food industry are lacking [13]. Previous studies did not properly consider the characteristics of latecomers [14] that arrived in the food industry and begun anew. In addition, the studies were mainly conducted on large firms. In the studies, the differences in characteristics according to the size of the firm were not sufficiently considered. An empirical study related to the sustainable innovation performance of medium-sized firms in latecomer countries is needed.

The studies on medium-sized firms' innovation in latecomer countries need to be approached from the perspective of industrial value chains, as it is difficult to meet the needs of stakeholders alone in terms of food supply $[15,16]$. Therefore, this study conducted an empirical study on medium-sized food firms in Korea, from the perspective of the industrial value chain. This study was conducted with 67 food firms with dedicated domestic research institutes. We performed a regression analysis of how government support, R\&D investment or cooperation networks affect each firm's sustainable innovation performance.

\section{Theoretical Background and Hypotheses}

\subsection{Sustainable Innovation}

Tello and Yoon [17] defined sustainable innovation as the development of new products, processes, services and technologies that contribute to the development and well-being of human needs and institutions while respecting the world's natural resources and regenerative capacity. Sustainable innovation is a critical dimension of sustainable development and a process where sustainability considerations, such as environmental, social and financial concerns, are integrated into the generation of new ideas, leading to new $R \& D$ and to new commercialization. Bos-Brouwers [18] presented sustainable innovation in which the renewal or improvement of products, services, and technological or organizational processes not only delivers an improved economic performance, but also an enhanced environmental and social performance, which, both in the short and long term, have the capacity to generate positive social and environmental impacts.

As food production is one of the major contributors to climate change, biodiversity loss, freshwater use and land system change, attempts to transform it in a sustainable way are emerging worldwide [19]. More research is being focused on the development of healthy, high-quality and safe foods suitable for consumer needs and more environmentally friendly processes [20].

\subsection{Innovation in Korean Food Industry}

According to "Global Data", which is a UK research and consulting company, the size of the global food market for manufacturing (food, alcoholic beverages, non-alcoholic beverages, and tobacco) and trade, excluding food services, is USD 6.49 trillion as of 2018 [21]. It was expected that the global economic market, which had deteriorated after the 2008 global financial crisis, will gradually recover, and the situation of the food market will also recover. However, after the COVID-19 pandemic, the economic situation contracted, and the outlook for the food market became unpredictable. 
The sales volume of the Korean food industry is USD 446 billion and the number of employees is 2.18 million [22]. According to the OECD [23], the growth rate of production, employment and exports of the Korean food industry exceeds that of most OECD countries. However, the absolute size of the food industry is still small and exports are limited. The global market share of Korean food has increased, but the comparative advantage is still inferior. R\&D investment is small compared to the size of the industry. In the food manufacturing industry, firms with annual average sales of less than USD 91 million account for $97.0 \%$ of the total number of firms, but only $57.9 \%$ of sales as of 2018 [21]. The structure of food industry is concentrated on some large firms with sales of more than USD 91 million.

It is important to identify opportunities for sustainable growth of food firms in the Korean context. Above all, the Korean food industry has a high proportion of large firms compared to SMEs. In addition, the competitive advantage of Korean traditional food's marketability and food safety technology level is still being verified. The food industry in Korea has developed well through a government-led system [24]. This industrial context in Korea demonstrates the need to move forward strategically to identify the sustainable growth opportunities of large companies and SMEs in the food industry [25]. Therefore, the challenge of the "Korean context" based on technology is to adopt innovation strategies for the sustainable growth of Korean food firms [26].

\subsection{Value Chain in Food Industry}

Agricultural and fishery products produced by primary producers are delivered to consumers through the food industry's value chain [27]. The food industry's value chain must take into account the potential for spoilage of food, food safety regulations, seasonality, and regional and cultural impacts [28]. The freshness of food is one of the important factors of food value and is managed through storage and transportation temperature, shelf life or quality maintenance period. The government ensures that quality products are delivered to consumers through food safety regulations. Each government is strengthening regulations on the safety of food, which can be directly connected to the lives of the people. In particular, foods imported from foreign countries are subject to strict customs procedures.

Recent climate change, with corresponding increases in $\mathrm{CO}_{2}$ levels, is affecting agricultural production [1]. Socioeconomic changes such as price hikes and hunger problems follow. Each actor in the value chain needs to promote sustainable growth by increasing productivity and profitability in a stable financial environment [29].

As the economy developed, the food industry trend has changed from supply-driven to demand-based [30]. In an era of oversupply, consumers are not satisfied with just filling their stomach. Consumers are interested in health, well-being, and high-quality food and demand those from producers [2]. Companies are trying to develop new products through R\&D activities using internal and external knowledge. External technology sources enable products with improved performance to be brought to market in a short time [31].

As food and services become more complex, potentially useful knowledge is more likely to be outside the business [32]. Food firms seek to acquire external knowledge through collaboration with external players to secure competitiveness. They establish complementary partnerships through alliances, cooperation and joint ventures with partners [33,34]. Previously, food firms preferred to establish partnerships with entities in similar sectors [35]. However, it also forms a cooperation network with firms in industries characterized by high levels of innovation. Collaboration with the biotech industry provides opportunities to increase added value [36]. In the case of nanotechnology, it has the potential to meet the demands of modern consumers, so it has limited application in the food industry [37].

Food firms rely heavily on external sources of information to innovate $[38,39]$. They form a partnership with suppliers, universities, research institutes and governments to innovate. The need for open innovation in the food industry is on account of unique characteristics of the food industry. Food innovations are often developed by small firms that may lack commercialization know-how [40]. 
They will try to compensate for these weaknesses through alliances with large companies. In addition, innovation in the food sector is incremental rather than radical [41,42], so partnerships with external organizations are essential. In addition, previous empirical studies have shown that knowledge useful for food firms comes from several scientific and technological sectors such as pharmaceuticals, chemicals and agriculture [41,43], machinery, tools and electricity.

\subsection{Hypotheses}

\subsubsection{Government's Support}

Government-supported firms increase their R\&D investments to achieve sustainable performance. Government support to firms' R\&D is in the form of free or low-interest capital assistance, tax breaks, deregulation, etc.; government-supported firms invest in hiring people or purchasing equipment for R\&D. Previous studies have indicated that German venture firms that are supported by the government had higher R\&D intensity than those that were not [44]. In the case of high-tech firms in China, government support has increased R\&D investment by firms [45]. However, government subsidies alone cannot cover the cost of entire R\&D projects. As such, private firms selected for government-funded projects have no choice but to increase their own R\&D investments.

Government support provides opportunities for R\&D organizations, including universities, to transfer basic scientific knowledge and skills to businesses [46]. Muscio, Quaglione and Vallanti [47] found that government funding for universities increases university-industry alliances and promotes knowledge transfer. Governments implement policies and strategies to improve partnerships between businesses and universities to promote innovation [48]. In countries where private investment is not active and knowledge bases and markets are lagging behind those of developed countries, government $R \& D$ funds are important drivers of innovation [49]. Firms that drive innovation are considering cooperation with universities to achieve their goals. Government policies can only be effective when there is a need to promote cooperation between firms and innovation partners [50].

Other firms in the same industry can be competitors in the market, but they can be the strongest partners when their interests match. In particular, the reasons why government-supported firms are pushing for partnerships with other firms are as follows. First, they share the need for innovation. Second, it is possible to contribute to better performance. Third, they can achieve the performance of the R\&D project within a set period of time. In Europe, an example of expanding R\&D projects through alliances between government-supported firms was studied [51]. Government-supported firms have already proven their competence in the project selection phase upon evaluation by the government. Thus, the preference for government-supported firms increases when selecting partners [52]. In addition, government support may play a role in indirectly strengthening R\&D alliances by reinforcing firms' absorptive capacities [53].

Government support has a positive effect on improving innovation performance. Kang and Park [49] argued in a study of small and medium-sized biotech firms in Korea that government funding has a direct and indirect impact on firms' innovation by promoting internal R\&D and cooperation. Buchmann and Kaiser [54] evaluated the effectiveness of subsidies for individual and joint research in the German biotechnology industry. They found that subsidies increased the number of patents. In a study of German startups, the number of patents in government-supported firms [55] increased. In addition, research on manufacturing firms in China has shown an increase in the number of patent applications and new product development of government-supported firms [56]. A number of studies have shown that government support has a positive effect on innovation outcomes, e.g., studies on Chinese high-tech firms found that government support has a positive effect on short-term innovation performance, but a negative effect on long run on innovation performance [57].

As discussed above, in most advanced countries, government support had positive impacts on $R \& D$ investment, cooperation networks, and innovation performance. Therefore, this study examined 
the following hypotheses regarding government support in the latecomer countries of the food industry. These all were based on SME business performance in a ten-year period, 2008-2017.

Hypothesis 1a (H1a). Government's support increases firms' RED investment.

Hypothesis $\mathbf{1 b} \mathbf{( H 1 b ) . ~ G o v e r n m e n t ~ s u p p o r t ~ i n c r e a s e s ~ f i r m s ' ~ c o o p e r a t i o n ~ w i t h ~ u n i v e r s i t i e s . ~}$

Hypothesis 1c (H1c). Government support increases firms' cooperation with other firms.

Hypothesis 1d (H1d). Government support increases firms' sustainable innovation performance.

\subsubsection{R\&D Investment}

When a firm considers entering into an R\&D partnership, its first choice is a university. Universities play a leading role in innovation and are important for firms' growth. In the age of global competition, industry-academia cooperation is a form of open innovation to develop niche technologies and commercialize them. Firms rely on universities for the research, expertise, and training they need. Universities also want to receive financial support from firms for practical research to realize their academic work. As such, the interests of firms and universities are harmonized, and firms are likely to increase their alliances with universities.

There are studies showing that SMEs rarely interact with universities [58], but companies cooperated with universities primarily to design new products [7]. Therefore, SMEs with limited capacity increase R\&D expenditure to cooperate with universities, expecting to reduce transaction costs, correct market failures, and increase productivity [59].

Enkel and Gassman [60] found that the most important external sources of knowledge came from customers, suppliers and competitors, although public and commercial research institutions also played a role. Brandenburger and Nalebuff [61] argued that it was better to cooperate with even competitors in meeting customers' needs and participate in shared value creation. Knudsen [35] presented food and beverage firms were better off working with customers, suppliers and competitors than private/public research institutions or consultants. Therefore, for food firms to achieve better performances, cooperation with other firms through R\&D investment will be required.

R\&D investment is positively related to firms' performance. According to Thornhill's [62] research on Canadian manufacturers, industries with high R\&D intensity grow faster. Innovative firms are advantageous because they can grow regardless of the state of their industry. Tsai and Wang [63] also found that internal R\&D investment influenced the continued success of innovation with many types of partners in a study using Taiwan's Technological Innovation Survey. Over time, as knowledge is organized into routine procedures or commercially available equipment, firms' innovative performances depend more on traditional R\&D investments [64].

The following hypotheses are examined to find out the impact of R\&D investment in medium-sized food firms in the latecomer countries during a ten-year period, 2008-2017.

Hypothesis 2a (H2a). RED investment increases firms' cooperation with universities.

Hypothesis $\mathbf{2 b} \mathbf{b} \mathbf{H} \mathbf{2 b})$. RED investment increases firms' cooperation with other firms.

Hypothesis 2c (H2c). RED investment increases firms' sustainable innovation performance.

\subsubsection{Cooperation with University}

The analytical framework between knowledge and innovation began to be systematized with the triple helix model created by Etzkowitz and Leydesdorff [65], which focused on the relationship 
among universities, industry and government. Universities, along with industry and government, have played an important role in the production of knowledge created in the public sector as an axis of innovation. Recently, there is a trend that the role of universities is becoming more important. Universities are an important source of knowledge for firms seeking radical innovation and promotion of innovative revenue growth in the absence of formal R\&D cooperation [66]. Universities maintain a network with firms by commercializing academic research and engaging researchers in consulting with firms. Firms that network with external organizations rely more on local universities for their industrial research, expertise and training. The shorter the distance between a firm and a university, the less cost and barriers to knowledge transfer. However, it was found that while firms affiliated with universities are highly innovative in terms of R\&D spending, their links with universities do not guarantee better financial performance [67]. Firm-university networks are expanding, but not all programs contribute to firms' performance. Accordingly, firms must choose the programs that best meet their goals. Small firms are less likely to cooperate in research and development with public research institutions, especially universities [68]. It is not easy to trace the impact of different types of university-enterprise interaction mechanisms on different types of outcomes [69].

Therefore, the following hypothesis is proposed for the cooperation relationship between medium-sized food firms and universities during a ten-year period, 2008-2017.

Hypothesis 3 (H3). The increasing of firms' cooperation with universities increases sustainable innovation performance.

\subsubsection{Cooperation with Other Firm}

As technology and innovation become more complex, firms cannot develop all the capabilities needed for innovation by themselves [70]. Most firms lack the necessary resources, cannot hire many professionals, and have a small portfolio of innovations [71]. The food sector is focused on consumer interests, hence to obtain a sustainable competitive advantage, firms place an emphasis on innovation to meet customer requirements, as well as on innovation to differentiate themselves from competitors. However, firms with limited internal capabilities have tried to innovate through networking. The traditional linear model of $R \& D$, the foundation of firm innovation, is also turning into a model with a variety of sources and networks that complement the firms' capabilities [70]. Empirical case studies have shown that working with other firms is the most frequent cooperation model for innovation [7]. Even competitive firms are more effective if they cooperate with their partners who complement their own resources and have resources related to their pursuit of innovation [72]. In general, there seems to be an agreement that cooperation between firms increases innovation performance. Nevertheless, there are few studies regarding how the cooperation of medium-sized firms in the food industry would affect the sustainable innovation performance in latecomer countries. Therefore, the following hypothesis is proposed. The analyzed result is based on the business performance of 10 years, 2008-2017.

Hypothesis 4 (H4). Increasing of firms' cooperation with other firms increases sustainable innovation performance.

Based on the relationship between investment and cooperation and performance, the research framework is illustrated in Figure 1. 


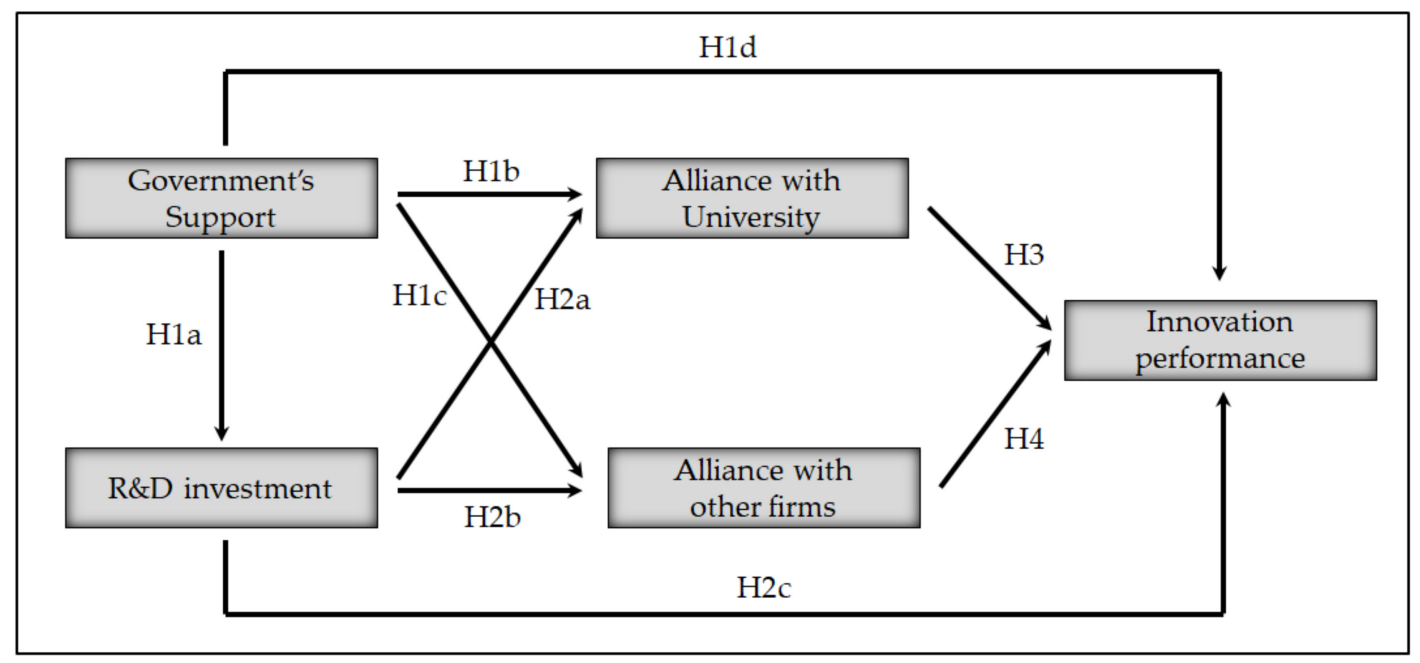

Figure 1. Structural equation model.

\section{Methodology}

\subsection{Data}

This study was conducted with 67 medium-sized firms in the food or beverage manufacturing sectors operating a research division in South Korea. In terms of SMEs, the food and beverage manufacturing industries have average annual sales of less than USD 85 million and USD 68 million, respectively. The subject of this study is a medium-sized firm registered with the Korea Industrial Technology Association (KOITA) [73] that manages the establishment and notification of changes in firms' R\&D organization. Animal feed-manufacturing was excluded from the study. The target period is 10 years, 2008-2017. In the "New normal 2.0" era after the 2008 global financial crisis, this study using data from 2008 to 2017 could be proactively applied to the COVID-19 pandemic situation [29]. The analysis data includes information on the number of employees, firm history, business area, number of registered patents, cooperation object, cooperation type, purpose of cooperation, etc. The basic information of the firm is based on the contents disclosed in the firms' electronic disclosures [74]. The number of patents registered in the Korea Intellectual Property Rights Information Service (KIPRIS) [75], provided by the Korean Intellectual Property Office (KIPO), was used for patent information.

Table 1 shows the status of food SMEs with firm-affiliated research divisions.

Table 1. Descriptive information on the medium-sized food firms.

\begin{tabular}{ccc}
\hline Characteristics & Number & Percentage \\
\hline Size (Number of employees) & & \\
$\leq 100$ & 21 & 31.3 \\
$101 \sim 300$ & 40 & 59.7 \\
$>300$ & 6 & 9 \\
\hline Age (years since foundation) & & \\
Young $(\leq 20)$ & 22 & 32.8 \\
Established $(>20)$ & 45 & 67.2 \\
\hline Business sectors & & \\
Food & 52 & 77.6 \\
Food additives & 9 & 16.9 \\
Functional food & 6 & 9 \\
\hline
\end{tabular}


Previously, no data had been established regarding cooperation in Korean value networks within the food industry. Therefore, in this study, a database on cooperation of Korean food firms was built by directly collecting data on cooperation among firms, especially medium-sized food firms. The analysis period is 10 years, 2008-2017. The data is sourced from a search term in 13 daily newspapers in Korea, wherein articles using the terms "cooperation, M\&A (mergers and acquisitions), joint venture, joint research, or MOU (memorandum of understanding)" were looked into. The total number of cooperation networks among firms found in 67 firms over 10 years is 114, giving an average of 0.17 per firm per year.

\subsection{Variables}

There are five explanatory and three control variables used in this study. Explanatory variables include (1) government support, (2) R\&D investment, (3) alliances with universities, (4) alliances with other firms, and (5) innovation performance.

First, government support is extended in various ways by selecting $R \& D$ fields or projects that contribute to the public interest that are difficult for businesses to handle on their own. Representative forms of support include direct increases in R\&D costs, such as subsidies or tax assistance, and manpower support, such as infrastructure or technical assistance, or support for the use of specialized research personnel or advanced research personnel. In addition, there is a form of support that helps firms obtain certifications or demand for their products. This study used technical support through firms' partnership with government-funded research institutes or local governments as a variable for government support.

Second, R\&D investment is essential for firms to develop new products and new technologies. It is one of the most important mechanisms for determining the level of innovation of a firm [76]. It is usually measured by R\&D expenditure standardized by firm size [77]. Therefore, this study divided the current developments or research expenses of firms' financial indicators by the corresponding annual sales and used it as a variable for R\&D investments.

Third, alliances with universities can improve sustainable innovation capacity by providing expertise and skills to firms [78]. As firms can receive the expertise and skills they desire from universities vis-à-vis other institutions more easily, they seek to achieve their goals through MOUs, joint research, and joint ventures with universities. In a relationship with a cooperation agreement, the following factors can be considered to assess the impact of cooperation on sustainable innovation performance; meeting productivity, products' productivity, overall productivity, research productivity, quality of research, and time burden [79]. However, this study studied whether an increase in cooperation increases innovation performance in quantitative terms. Therefore, the alliances with the university in the above-mentioned forms were measured; MOUs, joint research and joint venture.

Fourth, competing firms in the same industry can cooperate to achieve similar goals. MOUs or joint research can be used for conducting short and long-term research. In rare cases, a joint venture may be established. M\&As allow large firms to take over small firms or some business units to form small businesses as well as new ones. This study measured cooperation through alliances with other firms in the above-mentioned forms; joint venture, MOU, joint research and M\&A. In terms of the impact of cooperation with other firms on innovation performance, this study studied the increase or decrease relationship in quantitative terms as well as the relationship between cooperation with university and innovation performance.

Fifth, many patents are considered in measuring innovation performance, but they do not give a measure of the economic value of new technological creation [80]. However, citations and the number of new products along with patent registration are important indicators of technological innovation performance [81]. In the biotechnology industry, the number of patents registered by firms is considered a major R\&D performance indicator [49]. To measure sustainable innovation, some studies use the number of patents. Petruzelli, Dangelico, Rotolo and Albino [82] measured the value of green innovation by the number of patents. Markatou [83] used the number of patents to measure sustainable 
innovation in Greece. Aguilera-Caracuel and Ortiz-de-Mandojana [84] measured the strength of green innovation using the number of patents. Berrone, Fosfuri, Gelabert, and Gomez-Mejia [85] analyzed environment-related patents of publicly traded firms from polluting industries in the United States to measure environmental innovation. Therefore, in this study, the number of registered patents was used as the variable indicating the innovation performance.

Control variables include firm history, firm size, and business diversification. The size of the firm was measured by the number of employees. The history of a firm is the difference between 2017, the base year for the survey, and the year the firm was established. As a firm grows older, it can reduce its responsiveness to changes in the business environment. Moreover, the larger the size of firms, the better they become at securing and utilizing their resources and capacities [86]. Business diversification is a factor that determines the scope of the technology development process and the project. The business areas of food firms can be classified as (1) food (excluding animal feed; this study considers the industrial value chain system of the food industry), (2) food additives and (3) health functional foods. Therefore, this study used the number of business areas along with the firm's sales results as dummy variables for business diversification. The definitions of the variables are summarized in Table 2.

Table 2. Operational definitions of variables.

\begin{tabular}{|c|c|c|}
\hline Variables & Means & Operational Definitions \\
\hline gov_sup & Government support. & $\begin{array}{l}\text { Amount of government support (MOUs or joint } \\
\text { research between government and firms, and } \\
\text { policy funding). }\end{array}$ \\
\hline rnd_int & R\&D intensity. & Ratio of R\&D expenses to sales. \\
\hline univ_ally & Alliances with universities. & $\begin{array}{l}\text { Number of alliances with universities, including } \\
\text { MOUs, joint research, and joint venture. }\end{array}$ \\
\hline other_ally & Alliances with other firms. & $\begin{array}{l}\text { Number of alliances with other firms, including } \\
\text { MOUs, joint research, and joint venture. }\end{array}$ \\
\hline patent & Patent of registration. & $\begin{array}{l}\text { Number of patents registered by the firms in that } \\
\text { year (including joint patents). }\end{array}$ \\
\hline size & Firm's size. & Number of employees. \\
\hline age & Firm's age. & Number of years since founding. \\
\hline div_dum & $\begin{array}{l}\text { Dummy variable for business } \\
\text { diversification. }\end{array}$ & $\begin{array}{c}\text { Number of sectors in which a firm operates for } \\
\text { measuring the diversity of business operations } \\
\text { within a business. }\end{array}$ \\
\hline
\end{tabular}

\subsection{Analytic Model}

This study used the generalized structural equation model (GSEM) to verify the above hypotheses. GSEM is a method of verifying the causal relationship between variables, and their significance. It is an approach for simultaneously validating different types of models [87]. In particular, GSEM can support models with generalized response variables and deal with hierarchical structural models too [88]. This technique is suitable for verifying the effects of various explanatory variables that affect the dependent variables. This study focuses on demonstrating the impact of investment and cooperation on innovation performance. It also helps to determine whether the explanatory variable affects the dependent variable through various control variables (history, scale, and business diversification). The structural model presented in Figure 1 is illustrated by Equations (1)-(4). GSEM analysis was conducted using the statistical package STATA (version 13.0, Stata Corp, College Station, TX, USA) ( $\varepsilon$ is the error term for each indicator)

$$
\begin{gathered}
\text { rnd_int }=\beta_{0}+\beta_{1} \text { gov_sup }_{i}+\beta_{3} \text { size }_{i}+\beta_{4} \text { age }_{i}+\beta_{5} \text { div_dum }_{i}+\varepsilon_{i} \\
\text { univ_ally }=\beta_{0}+\beta_{1} \text { gov_sup }_{i}+\beta_{2} \text { rnd_int }_{i}+\beta_{3} \text { size }_{i}+\beta_{4} \text { age }_{i}+\beta_{5} \text { div_dum }_{i}+\varepsilon_{i}
\end{gathered}
$$




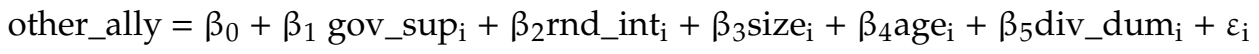

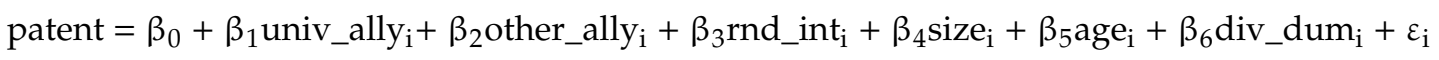

\section{Results}

Table 3 shows the means, standard deviations (SD) and correlations between variables. Table 4 shows analytic results by the GSEM.

Table 3. Descriptive statistics and correlation coefficients between variables.

\begin{tabular}{|c|c|c|c|c|c|c|c|c|c|c|}
\hline Variables & Mean & SD & Gov_Sup & Rnd_Int & Univ_Ally & Other_Ally & Patent & Size & Age & Div_Dum \\
\hline gov_sup & 0.051 & 0.239 & 1.000 & & & & & & & \\
\hline rnd_int & -5.008 & 1.555 & 0.028 & 1.000 & & & & & & \\
\hline univ_ally & 0.052 & 0.277 & $0.141^{* * *}$ & 0.073 * & 1.000 & & & & & \\
\hline other_ally & 0.066 & 0.260 & -0.006 & 0.045 & 0.056 & 1.000 & & & & \\
\hline patent & 0.352 & 0.944 & $0.087^{* *}$ & $0.139^{* * *}$ & $0.314^{* * *}$ & $0.315^{* * *}$ & 1.000 & & & \\
\hline size & 4.826 & 0.634 & 0.038 & $-0.220 * * *$ & $0.083^{* *}$ & 0.033 & 0.058 & 1.000 & & \\
\hline age & 3.050 & 0.630 & -0.018 & $0.112 * *$ & 0.007 & 0.019 & 0.039 & $\underset{* * *}{0.220}$ & 1.000 & \\
\hline div_dum & 1.221 & 0.575 & $0.179^{* * *}$ & $0.239 * * *$ & $0.209^{* * *}$ & 0.063 & $0.149^{* * *}$ & $\underset{* * *}{0.171}$ & $0.075^{*}$ & 1.000 \\
\hline
\end{tabular}

Notes: $\mathrm{N}=670, \mathrm{SD}=$ Standard deviations; the statistical result is the Pearson correlation coefficient; ${ }^{* * *} p<0.001$, ** $p<0.01, * p<0.05$.

Table 4. Analytic results

\begin{tabular}{ccccc}
\hline \multirow{2}{*}{$\begin{array}{c}\text { Explanatory } \\
\text { Variables }\end{array}$} & Rnd_Int & Univ_Ally & Other_Ally & Patent \\
\cline { 2 - 4 } & 1.176 & $0.917^{* * *}$ & -1.131 & $0.593^{* *}$ \\
gov_sup & & $0.270^{*}$ & 0.088 & $0.335^{* * *}$ \\
rnd_int & & & $2.311^{* * *}$ \\
univ_ally & & & $1.611^{* * *}$ \\
other_ally & $0.317^{* * *}$ & $0.689^{* * *}$ & 0.112 & 0.235 \\
size & $-0.029^{* *}$ & -0.387 & 0.119 & -0.227 \\
age & $0.514^{* * *}$ & $0.470^{* * *}$ & 0.339 & $0.117^{* * *}$ \\
div_dum & Note: $\mathrm{N}=670^{* * *} p<0.001^{* *} p<0.01, * p<0.05$.
\end{tabular}

The effects on the firms' size, history, and business diversification, which were used as control variables, are as follows. First, firms' size has a positive effect on increasing alliances with universities and innovation performance. Universities might promote stable businesses by selecting large firms as partners. Second, firms' history does not have any effect on investment, cooperation, and innovation performance. Third, business diversification had an effect on increasing alliances with universities and firms. Firms that diversify their businesses aim to develop new business materials through alliances with universities and other firms. Avermaete et al. [38] found that the firms' size, history and performance of local economies have some influence on innovation. However, this study found that a medium-sized firm's history does not affect sustainable innovation, and that a firm's size as well as business diversification do affect sustainable innovation.

As shown in Table 4, the results of hypotheses testing shown that government support for medium-sized food firms had a positive effect on alliances with universities and sustainable innovation performance, respectively, but did not have an effect on R\&D investment and alliances with other firms. In addition, R\&D investment had a positive effect on alliances with universities and sustainable innovation performance, but did not have an effect on alliances with other firms. Moreover, alliances with universities and alliances with other firms had a positive effect on sustainable innovation performance, respectively.

As a result of the analysis, this study does not support hypothesis H1a and H1c, but does support $\mathrm{H} 1 \mathrm{~b}$ and H1d. It is noteworthy that government support did not affect R\&D investment, even though 
Korea is a latecomer country where venture capital is not active. Government support might be focused on large firms rather than medium-sized firms, or it was conducted in other areas such as marketing and production, not R\&D for medium-sized firms. This is consistent with previous studies $[46,47,49,51,52]$ showing that government support has a positive impact on sustainable innovation performance either directly or indirectly through alliance with universities. As firms and universities share the same interests, they form alliances with each other with the government's support. Thus, medium-sized firms, lacking in-house research capabilities, are working with universities to obtain government support.

This study supports hypothesis $\mathrm{H} 2 \mathrm{a}$ and $\mathrm{H} 2 \mathrm{c}$, but not $\mathrm{H} 2 \mathrm{~b}$. R\&D investment had a positive effect on alliance with universities and sustainable innovation performance, but not alliance with other firms. Firms' R\&D is involved in the creation and application of new knowledge. As Liefner, Hennemann and Xin [7] and Pekkarinen and Harmaakorpi [59] argued, firms could conduct a radical innovation, reduce transaction costs, correct market failures, and increase productivity. Firms support $R \& D$ organizations by investing in the expansion of facilities and equipment, and by recruiting and training related personnel. In this way, firms improve their innovation performance through these investment activities [89]. In an environment where R\&D investment is small, medium-sized firms would tend to gain a competitive advantage by having their own technology and expertise rather than sharing R\&D results with other firms.

This study supports hypothesis H3. Alliances with universities have a positive effect on creating innovative performance. In open innovation, cooperation between firms and universities has been widely recognized as a major tool for strengthening organizational capacity. Open innovation has helped firms to not only enhance innovation, but also develop knowledge and complement existing internal $R \& D$ [90]. Firms are collaborating with universities for economic reasons and effectiveness resulting from lower costs associated with innovation [67]. A joint study of universities and industries can improve corporate sales, $R \& D$ productivity, and patent activities. Collaboration between universities and firms contributes towards fostering technology-based firms, especially SMEs, for business growth.

This study supports hypothesis H4. Alliance with other firms is not affected by government support or R\&D investment, but once cooperation with other firms is established, it has a positive impact on sustainable innovation performance. In line with Liefner, Hennemann and Xin [7] and Nieto and Santamaría [72], this study found that firms' alliances with other firms have a positive effect on creating innovative performance. Cooperation between firms, including competitors, can stimulate socio-economic progress by strengthening the development and use of knowledge, increasing the quantity and quality of goods and services, and expanding markets [91]. Medium-sized food firms cooperate with other firms for their own needs. Once they cooperate with other firms, they have an environment appropriate for innovation. Thus, a cooperative network among firms is likely the best strategy for sustainable innovation.

In sum, the results are shown in Figure 2.

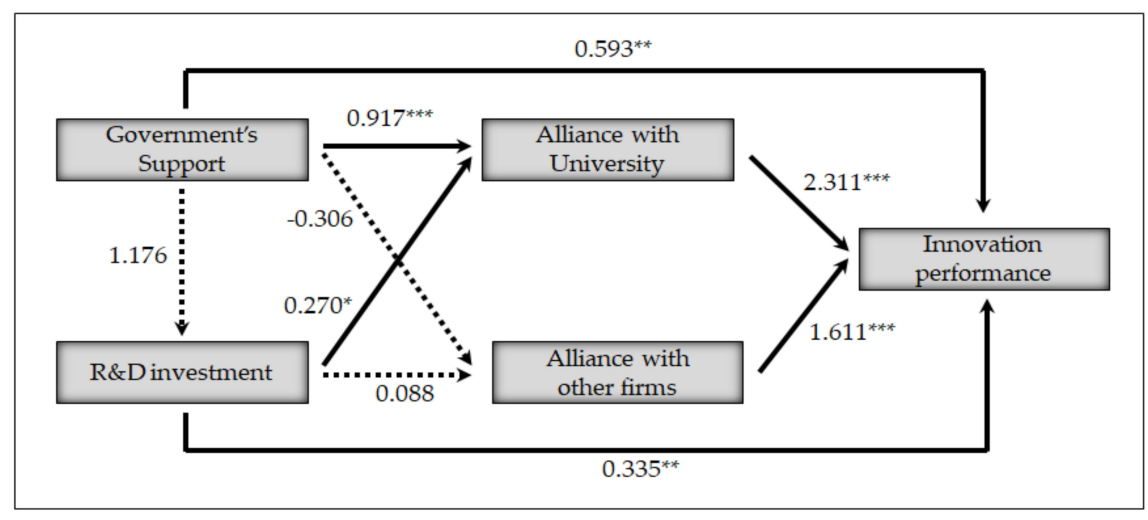

Figure 2. Structural model results; Notes: ${ }^{* *} p<0.001,{ }^{* *} p<0.01,{ }^{*} p<0.05$. 
Moreover, Table 5 presents the results of the analysis of the total effect to find out each path that influences innovation performance based on the structural equation model.

Table 5. Direct effect, indirect effect and total effect on innovation performance.

\begin{tabular}{cccc}
\hline \multirow{2}{*}{ Variables } & \multicolumn{3}{c}{ Innovation Performance } \\
\cline { 2 - 4 } & $\begin{array}{c}\text { Direct Effect } \\
\text { Coefficient }\end{array}$ & $\begin{array}{c}\text { Indirect Effect } \\
\text { Coefficient }\end{array}$ & $\begin{array}{c}\text { Total Effect } \\
\text { Coefficient }\end{array}$ \\
\hline Government support & 0.593 & 2.119 & 2.712 \\
R\&D investment \\
$\begin{array}{c}\text { Alliances with } \\
\text { universities }\end{array}$ & 0.335 & 0.630 & 0.962 \\
$\begin{array}{c}\text { Alliances with other } \\
\text { firms }\end{array}$ & 2.311 & 0 & 2.311 \\
\hline Total & 1.611 & 0 & 1.611 \\
\hline
\end{tabular}

\section{Conclusions}

This study examined the impact of government support, firms' R\&D investment and cooperation networks on medium-sized food firms' performance in the case of South Korea.

The implications for firm managers and government policy formulators can be drawn from the results. It was found that government support did not affect $R \& D$ investment. The failure of the government's support for food SMEs to improve innovation performance is likely due to firms' use of the resources provided by the government to replace the resources that firms should invest in. In order to eliminate this crowding-out effect on SMEs, the government needs to select firms with clear innovation goals and monitor their innovation process. Food SMEs, of course, should invest, but in the end, it is necessary to pay attention to system improvement, which inevitably leads to innovative performance. Food SMEs could consider investing in hygiene systems such as HACCP (Hazard Analysis Critical Control Point) and GMP (Good Manufacturing Practice) in order to improve food safety, consumer safety, or traceability.

Firms that receive government support or invest in $R \& D$ increase innovation performance through cooperation with universities. This is consistent with previous studies such as Liefner et al. [7], and Pekkarinen and Harmaakorpi [59]. Firms wishing to select a partner institution need to consider the university as their partner first. Since universities play a sufficient role in supplementing the lack of research capabilities in SMEs, various innovation projects can be considered.

On the other hand, government support or R\&D investment failed to promote alliance with other companies. Because the food industry is characterized by low technology, low entry barriers, and difficulty in differentiation, they have a closed relationship with a few cooperations between homogenous firms. To solve these problems, managers need to drive innovation with open innovation. Open innovation could help SMEs enhance innovation and complement internal R\&D [90].

This study filled the literature gap by exploring which innovation strategies should be used to improve the food SMEs' innovation performance in the latecomer countries to the food industry. Previously, very few empirical studies had been done on this subject. This study directly collected data on medium-sized food firms in South Korea and analyzed it with a structural equation model.

Despite this contribution, it has the following limitations. First, the number of support initiatives may not be sufficient to assess government support. Even considering the situation where the support is mainly for large firms or the government support for food SMEs is little, it may seem that the observed government support initiative is insufficient. Second, this study is only for medium-sized firms. Thus, it is insufficient to identify the performance of large firms leading the food industry in latecomer countries. In Korea, as less than $3 \%$ of large firms account for more than $55 \%$ of the total food and beverage industry's sales, studies on medium-sized firms are limited. Third, in terms of innovation, only the patent results were considered, and not the results of new product development. Unlike other high-tech industries, in the food sector, patents do not guarantee a monopoly on the 
market. Fourth, the relationship between innovation and financial performance has not been identified. It is not known how the innovation performance will affect the profitability of a firm. To overcome these limitations, additional research with more panel data should be undertaken to ensure that there are enough support initiatives to assess government support. In addition, future studies need to include large firms in the scope of study, measure new product development performance as innovation performance, and identify the relationship between innovation and financial performance.

Author Contributions: H.J. and K.S. worked together and significantly contributed to this paper; H.J. contributed to the literature review, study modeling, collection of data and writing; K.S. designed this study and contributed to the implementation and evaluation of the analytical model. All authors discussed the implications and approved the final manuscript. All authors have read and agreed to the published version of the manuscript.

Funding: This research received no external funding.

Conflicts of Interest: The authors declare no conflict of interest.

\section{References}

1. Parry, M.L.; Rosenzweig, C.; Iglesias, A.; Livermore, M.; Fischer, G. Effects of Climate Change on Global Food Production Under SRES Emissions and Socio-Economic Scenarios. Glob. Environ. Chang. 2004, 14, 53-67. [CrossRef]

2. Aguilera, J.M. Seligman Lecture 2005 Food Product Engineering: Building the Right Structures. J. Sci. Food Agric. 2006, 86, 1147-1155. [CrossRef]

3. Van der Valk, W.; Wynstra, F. Supplier Involvement in New Product Development in the Food Industry. Ind. Mark. Manag. 2005, 34, 681-694. [CrossRef]

4. Desouza, K.C.; Awazu, Y.; Jasimuddin, S. Utilizing External Sources of Knowledge. KM Rev. 2005, 8, 16-19.

5. Hewitt-Dundas, N. Resource and Capability Constraints to Innovation in Small and Large Plants. Small Bus. Econ. 2006, 26, 257-277. [CrossRef]

6. Fischer, M.M.; Varga, A. Technological Innovation and Interfirm Cooperation: An Exploratory Analysis using Survey Data from Manufacturing Firms in the Metropolitan Region of Vienna. Int. J. Technol. Manag. 2002, 24, 724-742. [CrossRef]

7. Liefner, I.; Hennemann, S.; Xin, L. Cooperation in the Innovation Process in Developing Countries: Empirical Evidence from Zhongguancun, Beijing. Enviorn. Plan. A 2006, 38, 111-130. [CrossRef]

8. Kaminski, P.C.; de Oliveira, A.C.; Lopes, T.M. Knowledge Transfer in Product Development Processes: A Case Study in Small and Medium Enterprises (SMEs) of the Metal-Mechanic Sector from Sao Paulo, Brazil. Technovation 2008, 28, 29-36. [CrossRef]

9. Mateev, M.; Anastasov, Y. Determinants of Small and Medium Sized Fast Growing Enterprises in Central and Eastern Europe: A Panel Data Analysis. Financ. Theory Pract. 2010, 34, 269-295.

10. Mulhern, A. The SME Sector in Europe: A Broad Perspective. J. Small Bus. Manag. 1995, 33, 83.

11. Terziovski, M. Innovation Practice and its Performance Implications in Small and Medium Enterprises (SMEs) in the Manufacturing Sector: A Resource-based View. Strateg. Manag. J. 2010, 31, 892-902. [CrossRef]

12. Cheng, C.C.; Shiu, E.C. Establishing a Typology of Open Innovation Strategies and their Differential Impacts on Innovation Success in an Asia-Pacific Developed Economy. Asia Pac. J. Manag. 2019, 1-25. [CrossRef]

13. Acosta, M.; Coronado, D.; Ferrándiz, E. Trends in the acquisition of external knowledge for innovation in the food industry. In Open Innovation in the Food and Beverage Industry; Elsevier: Amsterdam, The Netherlands, 2013; pp. 3-24.

14. Mathews, J.A. Latecomer Strategies for Catching-Up: The Cases of Renewable Energies and the LED Programme. Int. J. Technol. Learn. Innov. Dev. 2007, 1, 34-42. [CrossRef]

15. Grunert, K.G.; Jeppesen, L.F.; Jespersen, K.R.; Sonne, A.; Hansen, K.; Trondsen, T.; Young, J.A. Market Orientation of Value Chains. Eur. J. Mark. 2005, 39, 428-455. [CrossRef]

16. Costa, A.I.; Jongen, W. New Insights into Consumer-Led Food Product Development. Trends Food Sci. Technol. 2006, 17, 457-465. [CrossRef]

17. Tello, S.F.; Yoon, E. Examining Drivers of Sustainable Innovation. Int. J. Bus. Strategy 2008, 8, $164-169$.

18. Bos-Brouwers, H.E.J. Corporate Sustainability and Innovation in SMEs: Evidence of Themes and Activities in Practice. Bus. Strategy Environ. 2010, 19, 417-435. [CrossRef] 
19. De Bernardi, P.; Azucar, D. The Food System Grand Challenge: A Climate Smart and Sustainable Food System for a Healthy Europe. In Innovation in Food Ecosystems; Springer: Berlin/Heidelberg, Germany, 2020; pp. 1-25.

20. Betoret, E.; Calabuig-Jiménez, L.; Betoret, N.; Barrera, C.; Segui, L.; Fito, P. Sustainable innovation in food science and engineering. In Innovation Strategies in the Food Industry; Elsevier: Amsterdam, The Netherlands, 2016; pp. 149-165.

21. Korea Agro-Fisheries \& Food Trade Corporation. 2020 Statistics for Food and Food Service (Korean); Korea Agro-Fisheries \& Food Trade Corporation: Naju, Korea, 2020; pp. 1-425.

22. Korean Statistical Information Service. Available online: http://www.kosis.kr (accessed on 8 September 2020).

23. OECD. OECD Economic Surveys: Korea; OECD: Paris, France, 2018; p. 160.

24. Casper, S. Institutional Adaptiveness, Technology Policy, and the Diffusion of New Business Models: The Case of German Biotechnology. Organ. Stud. 2000, 21, 887-914. [CrossRef]

25. Mullins, J.W.; Komisar, R. Getting to Plan B: Breaking through to a Better Business Model; Harvard Business Press: Brighton, MA, USA, 2009.

26. Hitt, M.A.; Ireland, R.D.; Sirmon, D.G.; Trahms, C.A. Strategic Entrepreneurship: Creating Value for Individuals, Organizations, and Society. Acad. Manag. Perspect. 2011, 25, 57-75.

27. Porter, M.E. Competitive Advantage: Creating and Sustaining Superior Performance. Revista de Administração de Empresas 1985, 25, 82-84.

28. Fredriksson, A.; Liljestrand, K. Capturing Food Logistics: A Literature Review and Research Agenda. Int. J. Logist. Res. Appl. 2015, 18, 16-34. [CrossRef]

29. Jeong, H.; Shin, K.; Kim, E.; Kim, S. Does Open Innovation Enhance a Large Firm's Financial Sustainability? A Case of the Korean Food Industry. J. Open Innov. Technol. Mark. Complex. 2020, 6, 101. [CrossRef]

30. Schiefer, G.; Fritz, M.; Fortuin, F.T.; Omta, S.O. Innovation Drivers and Barriers in Food Processing. Br. Food J. 2009, 111, 839-851.

31. Eisenhardt, K.M.; Schoonhoven, C.B. Resource-Based View of Strategic Alliance Formation: Strategic and Social Effects in Entrepreneurial Firms. Organ. Sci. 1996, 7, 136-150. [CrossRef]

32. Bercovitz, J.E.; Feldman, M.P. Fishing Upstream: Firm Innovation Strategy and University Research Alliances. Res. Policy 2007, 36, 930-948. [CrossRef]

33. Enkel, E.; Gassmann, O.; Chesbrough, H. Open R \& D and Open Innovation: Exploring the Phenomenon. RD Manag. 2009, 39, 311-316.

34. Saguy, I.S. Paradigm Shifts in Academia and the Food Industry Required to Meet Innovation Challenges. Trends Food Sci. Technol. 2011, 22, 467-475. [CrossRef]

35. Knudsen, M.P. The Relative Importance of Interfirm Relationships and Knowledge Transfer for New Product Development Success. J. Prod. Innov. Manag. 2007, 24, 117-138. [CrossRef]

36. Maula, M.; Keil, T.; Salmenkaita, J.P. Open Innovation in Systemic Innovation Contexts [W:] Open Innovation: Researching a New Paradigm; Red, H.W., Chesbrough, W., Vanhaverbeke, J., Eds.; West Oxford University Press: Oxford, UK, 2006.

37. Juriaanse, A.C. Challenges Ahead for Food Science. Int. J. Dairy Technol. 2006, 59, 55-57. [CrossRef]

38. Avermaete, T.; Viaene, J.; Morgan, E.J.; Crawford, N. Determinants of Innovation in Small Food Firms. Eur. J. Innov. Manag. 2003, 6, 8-17. [CrossRef]

39. Sarkar, S.; Costa, A.I. Dynamics of Open Innovation in the Food Industry. Trends Food Sci. Technol. 2008, 19, 574-580. [CrossRef]

40. Fryer, P.J.; Versteeg, C. Processing Technology Innovation in the Food Industry. Innovation 2008, 10, 74-90. [CrossRef]

41. Galizzi, G.; Venturini, L. Product innovation in the food industry: Nature, characteristics and determinants. In Economics of Innovation: The Case of Food Industry; Springer: Berlin/Heidelberg, Germany, 1996; pp. $133-153$.

42. Grunert, K.G.; Harmsen, H.; Meulenberg, M.; Kuiper, E.; Ottowitz, T.; Declerck, F.; Traill, B.; Göransson, G. A framework for analysing innovation in the food sector. In Products and Process Innovation in the Food Industry; Springer: Berlin/Heidelberg, Germany, 1997; pp. 1-37.

43. Wilkinson, J. The R\&D Priorities of Leading Food Firms and Long-Term Innovation in the Agro Food System. Int. J. Technol. Manag. 1998, 16, 711-720.

44. Almus, M.; Czarnitzki, D. The Effects of Public R\&D Subsidies on Firms' Innovation Activities: The Case of Eastern Germany. J. Bus. Econ. Stat. 2003, 21, 226-236. 
45. Hong, J.; Feng, B.; Wu, Y.; Wang, L. Do Government Grants Promote Innovation Efficiency in China's High-Tech Industries? Technovation 2016, 57, 4-13. [CrossRef]

46. Carayannis, E.G.; Alexander, J.; Ioannidis, A. Leveraging Knowledge, Learning, and Innovation in Forming Strategic Government-university-industry (GUI) R\&D Partnerships in the US, Germany, and France. Technovation 2000, 20, 477-488.

47. Muscio, A.; Quaglione, D.; Vallanti, G. Does Government Funding Complement or Substitute Private Research Funding to Universities? Res. Policy 2013, 42, 63-75. [CrossRef]

48. Godin, B.; Gingras, Y. Impact of Collaborative Research on Academic Science. Sci. Public Policy 2000, 27, 65-73. [CrossRef]

49. Kang, K.; Park, H. Influence of Government R\&D Support and Inter-Firm Collaborations on Innovation in Korean Biotechnology SMEs. Technovation 2012, 32, 68-78.

50. Zeng, S.X.; Xie, X.M.; Tam, C.M. Relationship between Cooperation Networks and Innovation Performance of SMEs. Technovation 2010, 30, 181-194. [CrossRef]

51. Bach, L.; Matt, M.; Wolff, S. How do Firms Perceive Policy Rationales Behind the Variety of Instruments Supporting Collaborative R\&D? Lessons from the European Framework Programs. Technovation 2014, 34, 327-337.

52. Arend, R.J.; Bromiley, P. No Title. Assessing the dynamic capabilities view: Spare change, everyone? Strateg. Organ. 2009, 7, 75-90. [CrossRef]

53. Lin, C.; Wu, Y.; Chang, C.; Wang, W.; Lee, C. The Alliance Innovation Performance of R \& D Alliances-The Absorptive Capacity Perspective. Technovation 2012, 32, 282-292.

54. Buchmann, T.; Kaiser, M. The Effects of R\&D Subsidies and Network Embeddedness on R \& D Output: Evidence from the German Biotech Industry. Ind. Innov. 2019, 26, 269-294.

55. Cantner, U.; Kösters, S. Picking the Winner? Empirical Evidence on the Targeting of R \& D Subsidies to Start-Ups. Small Bus. Econ. 2012, 39, 921-936.

56. Guo, D.; Guo, Y.; Jiang, K. Government-Subsidized R\&D and Firm Innovation: Evidence from China. Res. Policy 2016, 45, 1129-1144.

57. Zhang, J.; Guan, J. The Time-Varying Impacts of Government Incentives on Innovation. Technol. Forecast. Soc. Chang. 2018, 135, 132-144. [CrossRef]

58. Cooke, P.N.; Boekholt, P.; Tödtling, F. The Governance of Innovation in Europe: Regional Perspectives on Global Competitiveness; Cengage Learning EMEA: Andover, UK, 2000.

59. Pekkarinen, S.; Harmaakorpi, V. Building Regional Innovation Networks: The Definition of an Age Business Core Process in a Regional Innovation System. Reg. Stud. 2006, 40, 401-413. [CrossRef]

60. Enkel, E.; Gassmann, O. Driving Open Innovation in the Front End. In Proceedings of the 7th European Academy of Management Conference (EURAM), Paris, France, 16-19 May 2007.

61. Nalebuff, B.J.; Brandenburger, A.; Maulana, A. Co-Opetition; HarperCollinsBusiness London: London, UK, 1996.

62. Thornhill, S. Knowledge, Innovation and Firm Performance in High-and Low-Technology Regimes. J. Bus. Ventur. 2006, 21, 687-703. [CrossRef]

63. Tsai, K.; Wang, J. External Technology Sourcing and Innovation Performance in LMT Sectors: An Analysis Based on the Taiwanese Technological Innovation Survey. Res. Policy 2009, 38, 518-526. [CrossRef]

64. Rothaermel, F.T.; Thursby, M. The Nanotech Versus the Biotech Revolution: Sources of Productivity in Incumbent Firm Research. Res. Policy 2007, 36, 832-849. [CrossRef]

65. Etzkowitz, H.; Leydesdorff, L. The Dynamics of Innovation: From National Systems and "Mode 2" to a Triple Helix of University-industry-government Relations. Res. Policy 2000, 29, 109-123. [CrossRef]

66. Belderbos, R.; Carree, M.; Lokshin, B. Cooperative R \& D and Firm Performance. Res. Policy 2004, 33, 1477-1492.

67. George, G.; Zahra, S.A.; Wood, D.R., Jr. The Effects of Business-university Alliances on Innovative Output and Financial Performance: A Study of Publicly Traded Biotechnology Companies. J. Bus. Ventur. 2002, 17, 577-609. [CrossRef]

68. Maietta, O.W. Determinants of University-firm R\&D Collaboration and its Impact on Innovation: A Perspective from a Low-Tech Industry. Res. Policy 2015, 44, 1341-1359.

69. Schut, M.; van Paassen, A.; Leeuwis, C.; Klerkx, L. Towards Dynamic Research Configurations: A Framework for Reflection on the Contribution of Research to Policy and Innovation Processes. Sci. Public Policy 2014, 41, 207-218. [CrossRef] 
70. Bullinger, H.; Auernhammer, K.; Gomeringer, A. Managing Innovation Networks in the Knowledge-Driven Economy. Int. J. Prod. Res. 2004, 42, 3337-3353. [CrossRef]

71. Van de Vrande, V.; De Jong, J.P.; Vanhaverbeke, W.; De Rochemont, M. Open Innovation in SMEs: Trends, Motives and Management Challenges. Technovation 2009, 29, 423-437. [CrossRef]

72. Nieto, M.J.; Santamaría, L. The Importance of Diverse Collaborative Networks for the Novelty of Product Innovation. Technovation 2007, 27,367-377. [CrossRef]

73. List of Firms Operating an Organization Dedicated to Research by KOITA. Available online: http://www.rnd. or.kr (accessed on 10 September 2020).

74. Corporate Disclosure Information. Available online: http:www.dart.fss.or.kr (accessed on 10 September 2020).

75. Patent Information. Available online: http:www.kipris.or.kr (accessed on 10 September 2020).

76. Baldwin, J.R.; Hanel, P. Innovation and Knowledge Creation in an Open Economy: Canadian Industry and International Implications; Cambridge University Press: Cambridge, UK, 2003.

77. Hall, L.A.; Bagchi-Sen, S. A Study of R\&D, Innovation, and Business Performance in the Canadian Biotechnology Industry. Technovation 2002, 22, 231-244.

78. Freel, M. External Linkages and Product Innovation in Small Manufacturing Firms. Entrep. Reg. Dev. 2000, 12, 245-266. [CrossRef]

79. Mâsse, L.C.; Moser, R.P.; Stokols, D.; Taylor, B.K.; Marcus, S.E.; Morgan, G.D.; Hall, K.L.; Croyle, R.T.; Trochim, W.M. Measuring Collaboration and Transdisciplinary Integration in Team Science. Am. J. Prev. Med. 2008, 35, S151-S160. [CrossRef] [PubMed]

80. Acs, Z.J.; Anselin, L.; Varga, A. Patents and Innovation Counts as Measures of Regional Production of New Knowledge. Res. Policy 2002, 31, 1069-1085. [CrossRef]

81. Kleinknecht, A.; Van Montfort, K.; Brouwer, E. The Non-Trivial Choice between Innovation Indicators. Econ. Innov. New Technol. 2002, 11, 109-121. [CrossRef]

82. Messeni Petruzzelli, A.; Maria Dangelico, R.; Rotolo, D.; Albino, V. Organizational Factors and Technological Features in the Development of Green Innovations: Evidence from Patent Analysis. Innovation 2011, 13, 291-310. [CrossRef]

83. Markatou, M. Measuring'Sustainable'Innovation in Greece: A Patent Based Analysis. J. Innov. Bus. Best Pract. 2012, 2012, 1.

84. Aguilera-Caracuel, J.; Ortiz-de-Mandojana, N. Green Innovation and Financial Performance: An Institutional Approach. Organ. Environ. 2013, 26, 365-385. [CrossRef]

85. Berrone, P.; Fosfuri, A.; Gelabert, L.; Gomez-Mejia, L.R. Necessity as the Mother of 'green'inventions: Institutional Pressures and Environmental Innovations. Strateg. Manag. J. 2013, 34, 891-909. [CrossRef]

86. Thornhill, S.; Amit, R. Learning about Failure: Bankruptcy, Firm Age, and the Resource-Based View. Organ. Sci. 2003, 14, 497-509. [CrossRef]

87. Anderson, J.C.; Gerbing, D.W. Structural Equation Modeling in Practice: A Review and Recommended Two-Step Approach. Psychol. Bull. 1988, 103, 411. [CrossRef]

88. Rabe-Hesketh, S.; Skrondal, A.; Pickles, A. Generalized Multilevel Structural Equation Modeling. Psychometrika 2004, 69, 167-190. [CrossRef]

89. Protogerou, A.; Caloghirou, Y.; Vonortas, N.S. Determinants of Young Firms' Innovative Performance: Empirical Evidence from Europe. Res. Policy 2017, 46, 1312-1326. [CrossRef]

90. Coombs, R.; Harvey, M.; Tether, B.S. Analysing Distributed Processes of Provision and Innovation. Ind. Corp. Chang. 2003, 12, 1125-1155. [CrossRef]

91. Jorde, T.M.; Teece, D.J. Competition and Cooperation: Striking the Right Balance. Calif. Manag. Rev. 1989, 31, 25-37. [CrossRef]

Publisher's Note: MDPI stays neutral with regard to jurisdictional claims in published maps and institutional affiliations. 